\title{
Prevalence of Panton Valentine Leukocidin $(p v l)$ Gene in Methicillin Resistant Staphylococcus aureus Isolated from Market Samples of Chicken Meat
}

\author{
S. Wilfred Ruban ${ }^{1 *}$, R. Narendra Babu², Robinson J.J. Abraham², \\ T.M.A. Senthilkumar ${ }^{3}$, P. Kumaraswamy ${ }^{4}$, V. Appa Rao ${ }^{2}$ and K. Porteen ${ }^{5}$ \\ ${ }^{1}$ Department of Livestock Products Technology, Veterinary College, Bangalore, India \\ ${ }^{2}$ Department of Livestock Products Technology (Meat Science), \\ Madras Veterinary College, Chennai, India \\ ${ }^{3}$ Department of Animal Biotechnology, Madras Veterinary College, Chennai, India \\ ${ }^{4}$ Department of Bioinformatics and ARIS cell, Madras Veterinary College, Chennai, India \\ ${ }^{5}$ Department of Veterinary Public Health and Epidemiology, Madras Veterinary College, \\ Chennai, India \\ *Corresponding author
}

\begin{tabular}{|c|c|}
\hline & A B S T R A C T \\
\hline & \multirow{5}{*}{$\begin{array}{l}\text { The present study was conducted to evaluate the prevalence of Panton Valentine } \\
\text { Leukocidin ( } p v l \text { ) in methicillin resistant } S \text {. aureus isolated from Chicken meat marketed in } \\
\text { retail outlets in Chennai city, Tamil Nadu. A total of } 120 \text { meat samples were collected } \\
\text { from different retail outlets and it was observed that } 66.67 \text { ( } 80 / 120) \text { per cent of the samples } \\
\text { were positive for the presence of } S \text {. aureus. The isolates were screened for methicillin } \\
\text { resistance phenotypically by methicillin, oxacillin and cefoxitin disc diffusion assay and } \\
\text { for presence of } m e c A \text { gene by PCR. The results revealed that } 54 \text { isolates were positive for } \\
\text { presence of mecA gene by PCR indicating that the prevalence of methicillin resistant } S \text {. } \\
\text { aureus (MRSA) was } 67.5 \text { per cent. Comparison of different disc diffusion assays with } \\
\text { mecA PCR revealed that cefoxitin disc diffusion assay has sensitivity, specificity, Positive } \\
\text { predictive value (PPV), Negative predicative value (NPV) and accuracy of } 100,91,100,89 \\
\text { and } 95 \text { per cent respectively as compared to oxacillin and methicillin disc diffusion } \\
\text { assay.Both MRSA and Methicillin susceptible } S \text {. aureus (MSSA) were screened by PCR } \\
\text { for the presence of pvl gene and it was observed that } 38 \text { isolates carried pvl gene of which } \\
28 \text { isolates were MRSA and } 10 \text { isolates were MSSA indicating an overall prevalence of } \\
47.5 \text { per cent (38/80). The results of the present study indicates that MRSA isolated from } \\
\text { retail chicken meat carries pvl geneclearly indicating the presence of Community } \\
\text { associated-MRSA involving human contamination and hence proper hygiene is essential to } \\
\text { prevent possible ill effects to the consumers. }\end{array}$} \\
\hline $\begin{array}{l}\text { K e y w or d s } \\
\text { S. aureus, Chicken } \\
\text { meat, MRSA, mecA } \\
\text { gene, } p v l \text { gene }\end{array}$ & \\
\hline Article Info & \\
\hline $\begin{array}{l}\text { Accepted: } \\
\text { 20 March } 2017 \\
\text { Available Online: } \\
10 \text { April } 2017\end{array}$ & \\
\hline & \\
\hline
\end{tabular}

\section{Introduction}

S. aureus is a gram positive commensal pathogen commonly found in skin and nasal cavity of both human and animals. These organisms have evolved over decades as one of the pathogen to gain resistance to commonly used antibiotics in human and animal treatments. S. aureus is extraordinarily adaptable pathogen with a proven ability to 
develop resistance to antibiotics with majority of the genes encoding resistance being mediated through plasmids (Chambers and DeLeo, 2009). Methicillin resistance in Staphylococcus aureus (MRSA) in humans as well as in foods of animal origin and its prevalence has been increasing worldwide. This resistance is due to the acquisition of genes encoding a unique penicillin-binding protein (PBP2'or PBP2a) (Chen et al., 2009). Studies in different countries have strongly suggested that consumption of under cooked MRSA contaminated meat could be responsible for the prevalence of MRSA in the community (Ogata et al., 2102). Hence, there is an urgent need to document the prevalence of methicillin resistant $S$. aureus in meats marketed in retail outlets.

In addition, $S$. aureus especially MRSA often harbor gene encoding for Panton-Valentine leukocidin (PVL), and this is an exotoxin encoding gene and has been associated with most CA-MRSA (Community Associated MRSA) strains which causes severe skin infections and necrotizing pneumonia in human (Deurenberg et al., 2007). Since, S. aureus and MRSA have been found in human, food-producing animals and retail meat, the concern about the exposure for humans through the food chain is increasing day by day and hence the present study was aimed at evaluation of retail chicken meat samples for presence of mecA (associated with methicillin resistance) and PVL (virulence factor) genes.

\section{Materials and Methods}

The protocol and methodology used in the present study for isolation and characterization of $S$. aureus from Chicken meat was carried out with approval from Institutional Biosafety Committee of Tamil Nadu Animal and Veterinary Sciences University, Chennai.

\section{Study area and source of material}

A total of 120 chicken meat samples collected in sterile containers from different retail outlets in Chennai city (South, Central and North Zone) were used in his study.

\section{Isolation of Staphylococcus aureus}

Isolation of Staphylococcus aureus was done as per the standard procedure (ISO standard 6888/1:1999 and 6888/2: 1999). In brief, ten grams of each sample was added to $90 \mathrm{ml}$ of sterile Brain Heart Infusion broth supplemented with $10 \% \mathrm{NaCl}$ and enriched for $8-10$ hours at $37^{\circ} \mathrm{C}$. The enriched samples were streaked onto mannitol salt agar plates (Himedia, India) and were incubated for 24 to $48 \mathrm{~h}$ at $37^{\circ} \mathrm{C}$. The presumptive suspected colonies were identified by Gram staining, catalase test, mannitol fermentation, coagulase and thermonuclease test as per standard protocol.

\section{Reference strains}

The reference strains of $S$. aureus (MTCC 87) was obtained from Institute of Microbial Technology (IMTECH), Chandigarh and the reference strains of methicillin resistant $S$. aureus N- 315 (Juntendo University, Tokyo, Japan)were provided by Department of Veterinary Microbiology, Rajiv Gandhi Institute of Veterinary Education and Research (RIVER), Pondicherry were used in this study for standardization of PCR protocols.

\section{Disc diffusion assay}

Antibiotic susceptibility testing for detection of methicillin resistance among the isolates was performed by Kirby-Bauer disc diffusion method using methicillin $(5 \mu \mathrm{g})$, oxacillin (1 $\mu \mathrm{g})$ and cefoxitin $(30 \mu \mathrm{g})$ disc. A 0.5 McFarland standard suspension of the isolate 
was made and lawn culture done on Mueller Hinton agar plate and were incubated at $37^{0} \mathrm{C}$ for $18 \mathrm{~h}$ and zone diameters were measured. The sensitivity, specificity, positive predictive value and negative predictive value of the cefoxitin, oxacillin, and methicillin disk diffusion test in detecting phenotypic methicillin resistance in the $S$. aureus isolates using the presence of the mecA gene as "gold standard" as per the procedure outlined by Olowe et al., (2013).

\section{Polymerase chain reaction}

The genomic DNA was extracted by using DNA extraction kit (Qiagen) and the primers were custom synthesized. The sequences of the primers used for gene amplification are presented in Table 1. All oligonucleotide primers were custom synthesized by $\mathrm{M} / \mathrm{s}$. Eurofins, Bangalore. Polymerase chain reaction (PCR) for the detection of mecA and $p v l$ genes was performed according to the methods described by Merlino et al., (2002) and Lina et al., (1999). Briefly, amplification reactions were performed in a $25 \mu \mathrm{L}$ mixture containing $12.5 \mu \mathrm{L}$ of $2 \mathrm{X}$ PCR master mix (Amplicon, Denmark), 10pmol of each primers and $2 \mu \mathrm{L}$ of DNA template and the final volume was adjusted to $25 \mu \mathrm{L}$ by adding nuclease free water. Amplification reactions were performed using a DNA thermal cycler (Master Cycler Gradient, Eppendorf, Germany) with the following program: for mecA gene- denaturation for 5 minutes at $94^{\circ} \mathrm{C}$, followed by 35 cycles of denaturation for 1 minute at $95^{\circ} \mathrm{C}$, annealing for 30 seconds at $59^{\circ} \mathrm{C}$ and extension for one minute at $72^{\circ} \mathrm{C}$ and final extension for 5 minutes at $72^{\circ} \mathrm{C}$ and for $p v l$ gene- denaturation for 10 minutes at $95^{\circ} \mathrm{C}$, followed by 30 cycles of denaturation for 3 seconds at $94^{\circ} \mathrm{C}$, annealing for 30 seconds at $55^{\circ} \mathrm{C}$ and extension for one minute at $72^{\circ} \mathrm{C}$ and final extension for 10 minutes at $72^{\circ} \mathrm{C}$. The PCR products were stained with $1 \%$ solution of ethidium bromide and visualized under UV light after gel electrophoresis on $2.0 \%$ agarose gel. Nuclease free water was used as the negative control.

\section{Results and Discussion}

The results of the present study revealed that $66.67(80 / 120)$ per cent of the samples were positive for the presence of $S$. aureus. The results of the disc diffusion assay for detection of methicillin resistanceusing methicillin, oxacillin and cefoxitin are presented in table 2 and the sensitivity, specificity, Positive predictive value (PPV), Negative predicative value (NPV) and accuracy of this assay in comparison with $m e c A$ PCR are presented in table 3.

The result of the disc diffusion assay and comparison with mecA gold standard PCR clearly indicated that cefoxitin disc diffusion assay was superior compared to methicillin and oxacillin disc diffusion assay for detection of methicillin resistant $S$. aureus. Similarly, several workers have reported that the cefoxitin disc method has better sensitivity than the oxacillin disc method for MRSA detection (Pramodhini et al., 2011; Kali et al., 2014; Vyas et al., 2015). The higher sensitivity to cefoxitin can be explained by the increased expression of the $m e c A$-encoded protein $\mathrm{PBP} 2 \mathrm{a}$, as cefoxitin being an inducer of the mecA gene (Datta et al., 2012). In addition, Clinical and Laboratories Standards Institute (CLSI) (2010) recommends usage of cefoxitin $30 \mu \mathrm{g}$ disc for disc diffusion method for identification of MRSA.

In the present study, it was observed that 54 out of the $80 \mathrm{~S}$. aureus isolates screened by PCR amplified 533 bp product (Fig 1) specific for mecA gene as described by Merlino et al., (2002). PCR based on mecA gene is considered the gold standard method for detection of MRSA (Shahraz et al., 2012; Ahmed et al., 2014). Based on the results it 
was evident that the prevalence of MRSA in retail chicken meat marketed in Chennai was 67.5 per cent $(54 / 80)$. Similar prevalence of MRSA have been reported by Fesler et al., (2011) in chicken (37.2 \%), Karmi (2013) in chicken (24-52\%) and AgwuUluNnachi et al., (2014) in beef and goat meat $(85.7 \& 63.2$ $\%)$. However, in India no reports are presently available on the prevalence of MRSA in retail meats, however higher MRSA (80 \%) have been reported from human in hospital settings (Verma et al., 2000). Contrary to our findings lower prevalence of MRSA were recorded in various retail meats by Boost et al., (2013) in
Hong Kong (4.4 to $21.9 \%$ ), Wang et al., (2013) in China (1.7\%) and Eldaly et al., (2014) in Egypt (5 to $15 \%$ ). The literature clearly suggested that there is a considerable variation in the prevalence of MRSA in different countries and the variation may be attributed to factors like sample size, sampling and culture methods, regulation in use of antibiotics in farm animals, monitoring systems in place for use of antibiotics as growth promoters, unhygienic slaughter/ processing as well as regular screening of retail samples to evaluate the present status of MRSA.

Table.1 Primers used in this study

\begin{tabular}{|l|l|c|c|}
\hline Target gene & Sequence & $\begin{array}{c}\text { Product } \\
\text { size }\end{array}$ & Reference \\
\hline $\begin{array}{l}m e c A \\
\text { (Methicillin } \\
\text { Resistance) }\end{array}$ & $\begin{array}{l}\text { F-AAAATCGATGGTAAAGGTTGGC } \\
\text { R-AGTTCTGCAGTACCGGATTTGC }\end{array}$ & 533 bp & $\begin{array}{c}\text { Merlinoet al., } \\
(2002)\end{array}$ \\
\hline $\begin{array}{l}\text { (Panton- Valentine } \\
\text { Leukocidin) }\end{array}$ & F-ATCATTAGGTAAAATGTCTGGACATGATCCA & 433 bp & $\begin{array}{c}\text { Linaet al., } \\
(1999)\end{array}$ \\
\hline
\end{tabular}

Table.2 Results of disc diffusion assay of $S$. aureus isolated from retail chicken meat

\begin{tabular}{|l|c|c|}
\hline \multirow{2}{*}{ Antibiotics } & \multicolumn{2}{|c|}{ Chicken isolates $(\mathbf{n = 8 0})$} \\
\cline { 2 - 3 } & Sensitive & Resistant \\
\hline Methicillin & $44(55.00)$ & $36(45.00)$ \\
\hline Oxacillin & $28(35.00)$ & $52(65.00)$ \\
\hline Cefoxitin & $26(32.50)$ & $54(67.50)$ \\
\hline
\end{tabular}

Table.3 Comparison of methicillin, oxacillin and cefoxitin disc diffusion assay with $m e c A$ gene PCR for detection of methicillin resistant $S$. aureus

\begin{tabular}{|l|c|c|c|c|c|}
\hline & $\begin{array}{c}\text { Specificity } \\
(\boldsymbol{\%})\end{array}$ & $\begin{array}{c}\text { Sensitivity } \\
(\mathbf{\%})\end{array}$ & $\begin{array}{c}\text { PPV } \\
(\mathbf{\%})\end{array}$ & $\begin{array}{c}\text { NPV } \\
(\mathbf{\%})\end{array}$ & $\begin{array}{c}\text { Accuracy } \\
(\boldsymbol{\%})\end{array}$ \\
\hline Methicillin & 67 & 53 & 70 & 48 & 58 \\
\hline Oxacillin & 84 & 89 & 89 & 84 & 87 \\
\hline Cefoxitin & 100 & 91 & 100 & 89 & 95 \\
\hline
\end{tabular}

PPV: Positive Predictive Value; NPV: Negative Predictive Value 
Fig.1 PCR amplification of mecA (533 bp) gene in $S$. aureus isolated from chicken marketed in Chennai city

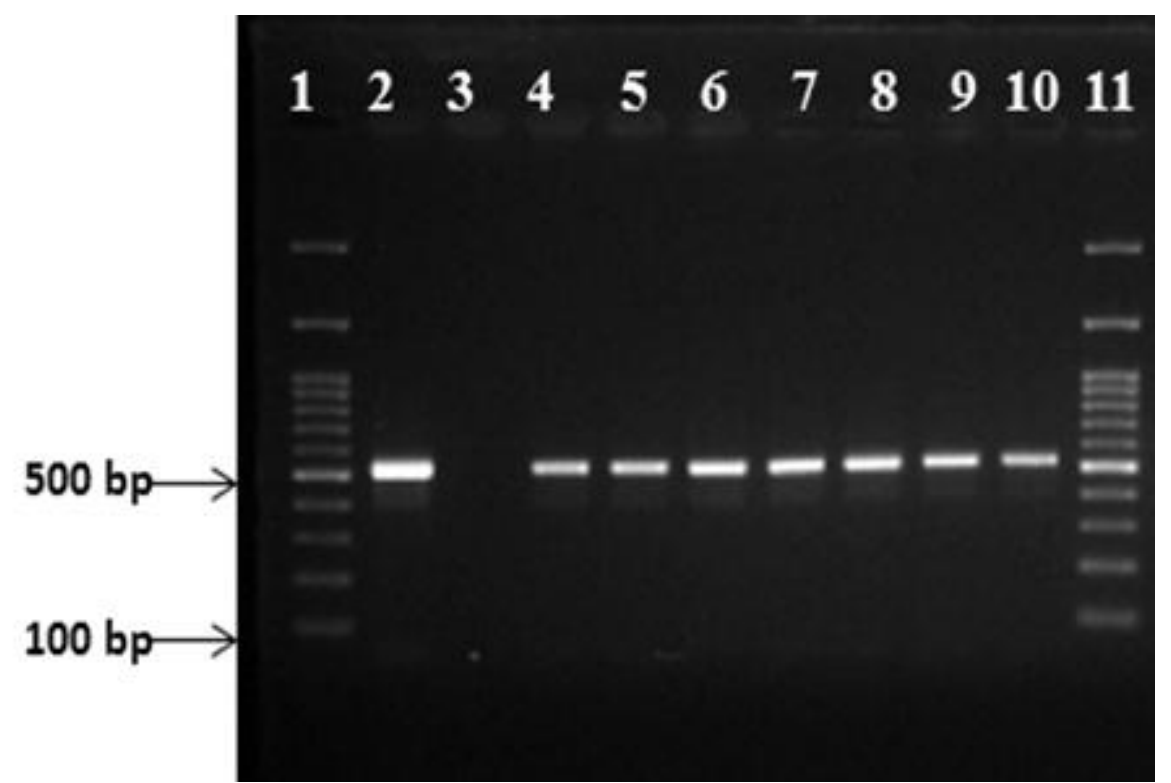

Lane 1\& 11: 100 bp DNA ladder, Lane 2: S. aureusstandard isolate, Lane 3: Negative Control, Lane 4-10: Isolates from Chicken meat positive for $m e c A$ gene

Fig.2 PCR amplification of $p v l$ (433 bp) gene in $S$. aureus isolated from chicken marketed in Chennai city

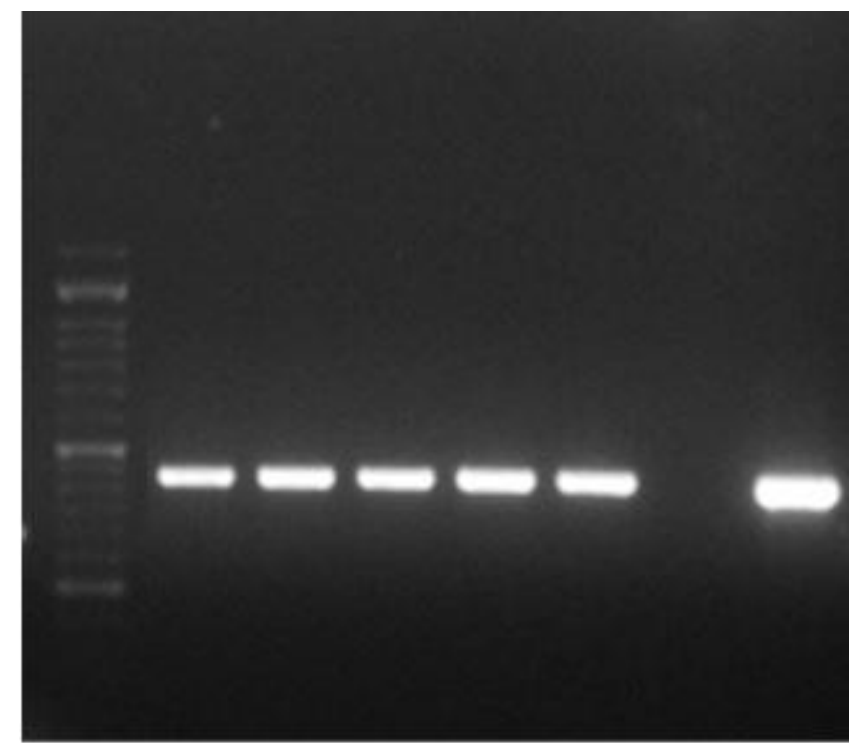

Lane M: 100 bp DNA ladder, Lane 1-6: S. aureus isolates from Chicken and Beef positive for $p v l$ gene; Lane 6: Negative Control and Lane 7: $p v l$ reference strain (MVCMSTC27)

All the 80 isolates (54 MRSA and 26 MSSA) were screened for the presence of PantonValentine leukocidin $(p v l)$ gene, a marker for
Community Associated MRSA (CA-MRSA) based on PCR and it was observed that that 38 isolates amplified 433 bp product specific for 
$p v l$ gene as described by Lina et al., (1999), of which 28 isolates were MRSA and 10 isolates were MSSA indicating an overall prevalence of 47.5 per cent (38/80). The results of the present study were in accordance with Bhutiaet al., (2012) and Kaur et al., (2012) in India who suggested that MRSA is an important reservoir of pvlgene and are now being slowly acquired by MSSA strains. Similarly, Abdalrahman et al., (2015) observed that 66.7 per cent MRSA isolates obtained from chicken meat carried $p v l$ gene.

In conclusion, the results of the present study clearly indicates that the retail chicken marketed in Chennai is highly contaminated with Methicillin resistant S. aureus (MRSA) and majority of these isolates also harbor $p v$ lgene, which encodes exotoxin responsible for virulence of these strains and with ability to causes severe skin infections in human and person in contact with such contaminated meat. In addition, PVL being a marker of CAMRSA, this study clearly indicates that the major source of contamination of meat is human handlers. However, further molecular characterization and validation of these isolates will provide better insights of the origin as well as source of contamination.

\section{Acknowledgement}

The author duly acknowledges the Dean, Madras Veterinary College, TANUVAS, Chennai for providing facilities for conduct of the research. This study is part of Ph.D thesis submitted by the first author to Tamil Nadu Animal and Veterinary Sciences University, Chennai.

\section{References}

Abdalrahman, L.S., H. Wells and Fakhr, M.K. 2015. Staphylococcus aureus is More Prevalent in Retail Beef Livers than in Pork and other Beef Cuts. Pathogens. 4: 182-198.
AgwuUluNnachi, F. E. Emele, C.O. Ukaegbu, M.V. Agah, O.E. Udu-Ibiam, O.S. Chukwu and Agwu, M. M. 2014. Prevalence of Methicillin-Resistant Staphylococcus aureus (MRSA) in Raw Meat and Meat Handlers in Onitsha, Nigeria.European Journal of Preventive Medicine.2(1): 9-15.

Ahmed, O. B., M. A. Elmekki, E. E. Omer, and Elhassan, M. M. 2014.Molecular detection of Methicillin resistant Staphylococcus aureus in patients with urinary tract infections in Khartoum State. Journal of Science and Technology. 15(2):1-8.

Bhutia, K.O., T.S. Singh, S. Biswas and Adhikari, L. 2012. Evaluation of phenotypic with genotypic methods for species identification and detection of methicillin resistant in Staphylococcus aureus. Int. J. App. Basic. Med. Res. 2:84-91

Boost, M.V., A. Wong, J. Ho, and O’Donoghue, M.2013. Isolation of Methicillin-Resistant Staphylococcus aureus (MRSA) from Retail Meats in Hong Kong.Foodborne Pathogens and Disease. 10(8): 1-7.

Chambers, H.F. and DeLeo, E.R. 2009. Waves of Resistance: Staphylococcus aureus in the Antibiotic Era. Nat. Rev. Microbiol. 7(9): 629-641.

Chen, L., J.R. Mediavilla, D.C. Oliveira, B.M. Willey, H. de Lencastre and Kreiswirth, B.N. 2009. Multiplex realtime PCR for rapid Staphylococcal cassette chromosome mectyping. Journal of Clinical Microbiology, 47: 3692-3706

CLSI (Clinical and Laboratory Standards Institute), 2010. Performance Standards for Antimicrobial Susceptibility Testing: Twentieth Information Supplement Wayne, PA.

Datta, S., Akter, A., Shah, I.G., Fatema, K., Islam, T. H., Bandyopadhyay, A., 
Khan, Z.U.M. and Biswas, D. 2012.Microbiological Quality Assessment of Raw Meat and Meat Products, and Antibiotic Susceptibility of Isolated Staphylococcus aureus.Agric. Food Anal.Bacteriol. 2(3): 187-194.

Deurenberg RH, Vink C, Kalenic S, Friedrich AW, Bruggeman CA, Stobberingh EE. The molecular evolution of methicillin-resistant Staphylococcus aureus.ClinMicrobiol Infect. 2007;13: 222-235.

Eldaly, E.A., N.F. El-Shopary and Gamal,R.H.E. 2014.Prevalence of methicillinresistant Staph.aureus (MRSA) in retail meat products in El-Gharbia Province, Egypt. Global J. Agric. Food Safety Sci. 1(2): 270-282.

Fesler, A.T, K. Kadlec, M. Hassel, T. Hauschild, C. Eidam, R. Ehricht, S. Monecke and Schwarz, S. 2011. Characterization of methicillin resistant Staphylococcus aureus isolates from food and food products of poultry origin in Germany. Appl. Environ. Microbiol. 77(20):7151-7157

ISO 6888-1: 1999. Horizontal methods for enumeration of coagulase positive Staphylococci (Stahylococcus aureus and other species). Part 1: Technique using Baird-Parker agar medium. International Organization for Standardization, Geneva, Switzerland.

ISO 6888-2: 1999. Horizontal methods for enumeration of coagulase positive Staphylococci (Stahylococcus aureus and other species.) Part 2: Technique using rabbit plasma fibrinogen agar medium. International Organization for Standardization, Geneva, Switzerland

Kali, A., S. Stephen and Umadevi, S. 2014. Laboratory evaluation of phenotypic detection of methicillin-resistant
Staphylococcus aureus. Biomed J. 37: 411-414.

Kaur, H., S. Purwar, A. Saini, K. Harbhajan, S.G. Karadesai, D.K. Sanjiva and Roy, S. 2012. Status of MRSAInfections and Evaluation of PVL Producing Strains in Belgaum, South India.Journal of Krishna Institute of Medical Sciences University. 1(2): 4351.

Lina, G., Y. Piemont, F. Godail-Gamot, M. Bes, M.O. Peter, V. Gauduchon, F. Vandenesch and Etienne, J. 1999. Involvement of Panton Valentine leukocidin-producing Staphylococcus aureus in primary skin infections and pneumonia.Clin. Infect. Dis. 29: $1128-1132$.

Merlino, J., J. Watson and Rose, B. 2002.Detection and expression of methicillin/oxacillin resistance in multidrug resistant and non-multidrug resistant Staphylococcus aureus in central Sydney, Australia. J. Antimicrob. Chemother. 49:793-798.

Ogata, K., H. Narimatsu, M. Suzuki, W. Higuchi, T. Yamamoto and Taniguchi, H.2012. Commercially distributed meat as a potential vehicle for community-acquired methicillinresistant Staphylococcus aureus. Appl. Environ. Microbiol. 78(8): 2797-2802.

Olowe, O. A., O. O. Kukoyi, S.S. Taiwo, O. Ojurongbe, O.O. Opaleye, O.S. Bolaji and Alli, O.T. 2013. Phenotypic and molecular characteristics of methicillin-resistant Staphylococcus aureus isolates from Ekiti State, Nigeria. Infection and Drug Resistance. 6: 87-92.

Pramodhini, S., P.R. Thenmozhivalli, R. Selvi, V. Dillirani, A. Vasumathi and Agatha,D. 2011.Comparison of Various Phenotypic Methods and mecA Based PCR for the Detection of MRSA. Journal of Clinical and 
Diagnostic Research. 5(7): 1359-1362.

Shahraz, F., H. Dadkhah and Khaksar, R.2012. Analysis of antibiotic resistance patterns and detection of mecA gene in $S$. aureus isolated from packaged hamburger. Meat Sci. 90(3): 759-763.

Verma, S., S. Joshi, V. Chitnis, N. Hemwani and Chitnis, D. 2000.Growing problem of methicillin resistant staphylococci- Indian Scenario. Ind. J. Med. Sci. 54: 535-40.

Vyas, A., M. Sharma, S. Kumar, M. Kumar and Mehra, S.K. 2015. A comparative study of Oxacillin screen agar, oxacillin disc diffusion and cefoxitin disc diffusion, oxacillin E-test method for routine screening of methicillin resistant $S$. aureus .International Journal of Current Research and Review. 7(10): 55-60.

Wang, X., Tao, X., Xia, X., Yang, B., Xi, M., Meng, J., Zhang, J. and $\mathrm{Xu}, \mathrm{B}$. 2013.Staphylococcus aureus and methicillin-resistant Staphylococcus aureus in retail raw chicken in China.Food Control. 29: 103-106.

\section{How to cite this article:}

Wilfred Ruban, R. Narendra Babu, Robinson J.J. Abraham, T.M.A. Senthilkumar, P. Kumaraswamy, V. Appa Rao and Porteen, K. 2017. Prevalence of Panton Valentine Leukocidin $(p v l)$ Gene in Methicillin Resistant Staphylococcus aureus Isolated from Market Samples of Chicken Meat. Int.J.Curr.Microbiol.App.Sci. 6(4): 2459-2466.

doi: https://doi.org/10.20546/ijcmas.2017.604.287 